\title{
PJIEE
}

\section{EMBRACING NEW NORMAL: COPING WITH COURSE LEARNING OUTCOMES AMID COVID-19 PANDEMIC}

\author{
by \\ Lina Septianasari \\ Sekolah Tinggi Keguruan dan Ilmu Pendidikan (STKIP) Muhammadiyah Bogor \\ linaseptiana27@gmail.com \\ Irma Wahyuni \\ Sekolah Tinggi Keguruan dan Ilmu Pendidikan (STKIP) Muhammadiyah Bogor \\ Wahyuni.irma@gmail.com
}

\begin{abstract}
:
Emergency remote teaching in the midst of the COVID-19 pandemic causes challenges in the educational field as many universities are not well-prepared yet to conduct virtual classes. This paper aims to throw light on the students' perception of emergency remote learning and their assessments in completing the Course Learning Outcomes (CLOs). The methods used in this study were statistical quantitative and descriptive qualitative methods. The data were collected by spreading questionnaires to the participants, having an unstructured interview, and taking the secondary data from the classroom teachers. LISREL software was used to analyze the quantitative data and descriptive interpretation was also done to analyze the qualitative data. The finding showed that most students had moderate to positive learning engagement, motivation, and self-efficacy in which affected their CLOs. The students who failed to pass the CLOs were those who faced more challenges in joining the virtual class. In short, students' ability to cope with emergency remote learning has significant impacts on their CLOs' assessments.
\end{abstract}

Key Words: Learning Outcomes, Remote Learning, ELT, COVID-19 Pandemic

\section{INTRODUCTION}

The massive outbreak of Covid-19 faced by many countries raises many problems including in the field of education (Heng \& Sol, 2020a; Mahyoob, 2020; ÖZÜDOĞRU, 2021). Face-to-face learning has to be shifted to online learning in a short span of time due to the rapid outbreak of this infectious disease. Even though online learning is not a new thing, it somewhat brings different challenges in education during this profound pandemic. The educational institutions 
prepared all the learning needs in a short time to cope with the global crisis. Coman et.al (2020) argued that the main challenge of the educational shift during the pandemic in Romania was the lack of preparedness to conduct online learning. This problem was also affected by technical issues, online teaching skills, and student-teacher engagement. Similar challenges also arose in other countries (read also: Cheng et.al., 2021; Besser, Lotem, \& Zeigler-Hill, 2020; and Azubuike, Adegboye, \& Quadri, 2020). It can never be denied that this emergency teaching mode brought more workloads for the institutions to prepare learning platforms and for the teachers to arrange teaching materials and assessment tools (Dhawan, 2020 and Heng \& Sol, 2020 b) in order to tackle the challenges. Education becomes a primary necessity for everyone; therefore, enormous efforts have been done to make it keep running exclusively amidst pandemics. After preparing the teaching tools and material and setting them up on LMS, it is necessary to investigate whether the students would be satisfied with what has already been prepared for a virtual class.

However, moving traditional teaching into synchronous-asynchronous online teaching provokes educators and education institutions to maximize the use of online platforms as multidevices to support online learning. Social media, MOOC (Massive Open Online Courses), and digital platforms significantly change learning habits (Pal \& Vanijja, 2020). Nowadays video conference platforms, such as Google Meet, Zoom, and Microsoft Teams, can be used in synchronous classes to bridge the transfer from the on-site classroom into the online classroom (Lapitan et.al., 2021). Even though many platforms can be utilized to support this emergency education system, educators and researchers seriously need to monitor how well the education system has been managed during this pandemic.

Some researchers lent their hands to investigate how education has run during this pandemic (Azubuike et al., 2020; Cheng et al., 2021; Dhawan, 2020; Espino-Díaz et al., 2020; Gonzalez et al., 2020; Hussein et al., 2020; Patricia, 2020). Hussein et al. (2020) have studied the attitude of undergraduate students towards emergency online learning in UAE and the findings showed that this sudden shift of learning brought negative and positive values for the students. Beneficially this learning system gave some advances to the students regarding cost and time effective compared to on-site classes. On the other hand, the students had difficulty concentrating and got more distractions to stay focused during the class (Hussein et al., 2020). It obviously becomes a big deal for the teachers to design effective learning activities to reach 
the learning outcomes of their courses. The stability of internet access can also be another problem in this case (Lapitan et al., 2021). The teachers are suggested to properly use an integrated approach in choosing a teaching platform to meet students' needs (Mozhaeva et al., 2014). Learning outcomes should be achieved by the students even though the learning process becomes more challenging in the emergency online class.

Measuring and assuring students' engagement in virtual class is important since this thing becomes one of the keys to successful teaching and learning process. Ashwin \& McVitty (2015) argued that students' engagement could define the quality of teaching in higher education. Further, they explained that this aspect also affects the outcomes of the students. Family, school, and peers become three factors that can build good students' engagement Ali \& Hassan (2018).

Bandura (1997) introduced the concept of self-efficacy which refers to the things that make people more motivated and these things influence how they think and behave. Zulkosky (2009)added that it affects the outcomes of the person himself. Talking about self-efficacy and students' motivation during this emergency remote learning, (Kosyicheva \& Tikhonova, 2021) surprisingly found out that the comparison of students' self-efficacy before and during emergency remote learning had no significant differences. Both groups were still at moderate levels of self-efficacy even though they prefer face-to-face learning to emergency remote learning. In line with this, Aldhahi et.al., 2021 stated that educators and the stakeholders in educational institutions played important roles to enhance students' self-efficacy during emergency remote learning. Generally speaking, these two actors should be proactive in preparing students' needs, such as interactive materials, supportive and accessible technology, learning media, etc., in order to develop fun yet effective learning amid pandemics. Students' motivation and self-efficacy also may affect students' performance and learning outcomes.

A well-thought plan is needed to manage the teaching and learning quality in New Normal, a phase to face the pandemic. Evaluation is needed to know how the emergency remote learning has run during New Normal. This study aimed to investigate (1) the students' perception in coping with emergency remote learning measured based on their engagement, motivation, and self-efficacy and (2) the assessments of students' learning outcomes in English class amid the COVID-19 pandemic. 


\section{METHOD}

\section{Design}

This study used a statistical quantitative approach to answer the research question. Apuke (2017) pointed out that numerical data were used in quantitative research to answer the research question. These data are collected and analyzed by using statistical methods. Thus, this study used a statistical approach to analyze the normality of data spread and to answer the research questions. The data were calculated by using LISREL software to find out the P-value, mean, and standard deviation of each datum.

\section{Population and sample}

Participants in this research are students at a private university in West Java, Indonesia. The population in this research was 356 students within 56 students were chosen as the sample by administering the purposive sampling technique. Participants should meet the criteria to be the sample of this study as they should be registered in English course and should participate in virtual class. These samples experienced learning English in face-to-face classes and online learning. Moreover, all the participants used LMS from Moodle and some free online learning platforms provided by their English lecturer. These platforms were used to support their learning during emergency remote learning due to the Covid-19 pandemic.

\section{Instrument and Data Type}

This research used primary and secondary data to answer the research questions. Cohen, Manion, \& Morrison (2007) defined primary data as the items that have a direct relationship with the study. Meanwhile, secondary data are defined as the items that have no direct event relationship with the study. The primary data of this research were taken from the questionnaire given to participants who experienced learning English in face-to-face classes and online classes. On the other hand, the secondary data were taken from the documents of students' achievement in completing Course Learning Outcomes (CLO) set and collected by the classroom lecturer. Moreover, we also conducted an unstructured interview purposely with our respected participants. 


\section{Data Collecting Technique}

The online questionnaire was designed to collect the data of this research. We managed 12 questions based on the research variable of this study. The following table shows the distribution of the questions!

Table 1. Distribution of questions in Questionnaire

\begin{tabular}{|c|c|c|c|}
\hline Variable & Dimension & $\begin{array}{l}\text { Indicator } \\
\text { code }\end{array}$ & Question \\
\hline \multirow{11}{*}{$\begin{array}{lr}\text { Students' } & \text { perception } \\
\text { of LMS } & \text { and online } \\
\text { learning } & \text { platforms } \\
\text { amid } & \text { pandemic } \\
\text { covid-19 } & \end{array}$} & \multirow[t]{3}{*}{$\begin{array}{l}\text { Students' } \\
\text { engagement }\end{array}$} & $\begin{array}{l}\text { Eng-1 } \\
\text { Eng-2 }\end{array}$ & $\begin{array}{l}\text { My ability to complete the task on time } \\
\text { My time management to study during } \\
\text { online learning by LMS and other tools } \\
\text { is., }\end{array}$ \\
\hline & & Eng-3 & $\begin{array}{l}\text { My knowledge of the use of learning } \\
\text { tools: }\end{array}$ \\
\hline & & Eng-4 & $\begin{array}{l}\text { My ability to discuss topics with } \\
\text { classmates/ lecturers }\end{array}$ \\
\hline & \multirow[t]{4}{*}{$\begin{array}{l}\text { Students' } \\
\text { motivation }\end{array}$} & Mot-1 & $\begin{array}{l}\text { My motivation to be successful in class } \\
\text { during online learning is }\end{array}$ \\
\hline & & Mot-2 & $\begin{array}{l}\text { My motivation to study during online } \\
\text { learning by LMS and other devices is }\end{array}$ \\
\hline & & Mot-3 & $\begin{array}{l}\text { My motivation to complete the individual } \\
\text { and groups projects during online } \\
\text { learning }\end{array}$ \\
\hline & & Mot-4 & $\begin{array}{l}\text { My motivation to be an independent } \\
\text { learner is }\end{array}$ \\
\hline & \multirow[t]{4}{*}{$\begin{array}{l}\text { Students' self- } \\
\text { efficacy }\end{array}$} & SE-1 & $\begin{array}{l}\text { How have your skills changed since the } \\
\text { study at home with LMS? }\end{array}$ \\
\hline & & SE-2 & $\begin{array}{l}\text { I can complete the learning outcomes in } \\
\text { online English classes with a satisfying } \\
\text { grade }\end{array}$ \\
\hline & & SE-3 & $\begin{array}{l}\text { English Course Material in LMS helps } \\
\text { me to enhance my knowledge }\end{array}$ \\
\hline & & SE-4 & $\begin{array}{l}\text { I still can manage my concentration and } \\
\text { gain more knowledge in the online class }\end{array}$ \\
\hline
\end{tabular}

To find out the objective measurement of students' ability in passing the CLO, we took the documents of students' grading system for 1 semester from the classroom lecturer. This document showed students' performance from the first meeting until the last meeting during emergency remote learning. After investigating the grading books, we called some participants who could not pass the CLO to find the cause of students' failures. 


\section{Data Analysis Technique}

The Likert scale was used to measure the data which then have been analyzed further by using LISREL software. This software was used to measure the normal distribution of the data. The following formula, adapted from Riadi (2018) was used to measure the data distribution:

If $\mathrm{P}-$ Value $<0.05$, data were not normally distributed

If $\mathrm{P}-$ Value $>0.05$, data were normally distributed

To find out students' grades in reaching the CLOs, the document of students' report was taken from their classroom lecturer. The report showed students' grades during 1 semester and how they completed the required 4 CLOs as the requirement to pass this course. This document then became the main data source to map students' achievement in passing the CLO.s The interview's results were also analyzed descriptively to get more findings of students' achievement in passing the CLOs. This article is processed with help of referencing tool Mendeley following the model of offline automatic system by using Mendeley Desktop (Turmudi, 2020).

\section{RESULT AND DISCUSSION}

\section{Results}

We used 3 criteria to investigate students' perceptions, such as engagement, motivation, and self-efficacy. These criteria were chosen by considering the findings of some previous research (Heng \& Sol, 2020b; Hussein et al., 2020; Lapitan et al., 2021; Mozhaeva et al., 2014). After formulating the questionnaire, we distributed the questionnaire to the participants of this study to find out the measurements of their engagement, motivation, and self-efficacy in joining emergency remote learning. The following tables show the findings of this study.

Table 2. Result of Test of univariate normality for continuous variable

\begin{tabular}{lllllll}
\hline \multirow{2}{*}{$\begin{array}{l}\text { Question } \\
\text { code }\end{array}$} & \multicolumn{2}{c}{ Skewness } & \multicolumn{2}{c}{ Kurtosis } & \multicolumn{2}{c}{ Skewness and Kurtosis } \\
\cline { 2 - 6 } Zng-Score & P-Value & Z-Score & P-Value & Chi-Square & P-Value \\
\hline Eng-2 & -0.535 & 0.592 & -2.035 & 0.042 & 4.430 & 0.109 \\
Eng-3 & -1.375 & 0.169 & -0.855 & 0.393 & 2.620 & 0.270 \\
Eng-4 & -0.477 & 0.633 & 0.162 & 0.872 & 0.254 & 0.881 \\
Mot-1 & -0.124 & 0.901 & -2.013 & 0.044 & 4.067 & 0.131 \\
& -0.414 & 0.679 & -1.797 & 0.072 & 3.402 & 0.182
\end{tabular}




\begin{tabular}{lllllll} 
Mot-2 & -0.916 & 0.360 & -1.379 & 0.168 & 2.740 & 0.254 \\
Mot-3 & -1.064 & 0.287 & -0.897 & 0.370 & 1.936 & 0.380 \\
Mot-4 & -0.688 & 0.492 & -2.053 & 0.040 & 4.689 & 0.096 \\
SE-1 & -1.168 & 0.243 & -1.115 & 0.265 & 2.608 & 0.271 \\
SE-2 & -0.082 & 0.935 & -0.652 & 0.515 & 0.432 & 0.806 \\
SE-3 & -0.920 & 0.358 & -1.086 & 0.277 & 2.025 & 0.363 \\
SE-4 & 0.609 & 0.542 & -1.526 & 0.127 & 2.701 & 0.259 \\
\hline
\end{tabular}

Table 2 above tells that the data were normally distributed since the scores of P-Value in Skewness and Kurtosis scores were more than 0.05. As previously stated by (Riadi, 2018), a set of data could be considered well-distributed when the P-Value is more than 0.05 (P-Value > $0.05)$ and vice versa.

Table 3. Result of Mean and Standard Deviation

\begin{tabular}{|c|c|c|c|}
\hline $\begin{array}{l}\text { Variable } \\
\text { code }\end{array}$ & Question & Mean & $\begin{array}{l}\text { Standard } \\
\text { Deviation }\end{array}$ \\
\hline Eng-1 & My ability to complete the task on time & 3.357 & 1.034 \\
\hline Eng-2 & $\begin{array}{l}\text { My time management to study during online learning by } \\
\text { LMS and other tools is., }\end{array}$ & 4.107 & 0.779 \\
\hline Eng-3 & My knowledge of the use of learning tools: & 3.839 & 0.682 \\
\hline Eng-4 & My ability to discuss topics with classmates/ lecturers & 3.196 & 1.069 \\
\hline Mot-1 & $\begin{array}{l}\text { My motivation to be successful in class during online } \\
\text { learning is }\end{array}$ & 3.339 & 1.100 \\
\hline Mot-2 & $\begin{array}{l}\text { My motivation to study during online learning by LMS } \\
\text { and other devices is }\end{array}$ & 3.179 & 1.097 \\
\hline Mot-3 & $\begin{array}{l}\text { My motivation to complete the individual and groups } \\
\text { projects during online learning }\end{array}$ & 3.268 & 1.152 \\
\hline Mot-4 & My motivation to be an independent learner is & 3.375 & 1.037 \\
\hline SE-1 & $\begin{array}{l}\text { How have your skills changed since the study at home } \\
\text { with LMS? }\end{array}$ & 4.071 & 0.783 \\
\hline SE-2 & $\begin{array}{l}\text { I can complete the learning outcomes in online English } \\
\text { classes with a satisfying grade }\end{array}$ & 3.411 & 0.804 \\
\hline SE-3 & $\begin{array}{l}\text { English Course Material in LMS helps me to enhance my } \\
\text { knowledge }\end{array}$ & 4.321 & 0.606 \\
\hline SE-4 & $\begin{array}{l}\text { I still can manage my concentration and gain more } \\
\text { knowledge in the online class }\end{array}$ & 3.696 & 0.807 \\
\hline
\end{tabular}

We also calculated the mean and standard deviation of the data we took from 56 participants. This step was done for describing the perceptions of participants regarding their engagement, motivation, and self-efficacy in learning English during emergency remote learning. The following graph visualized the scores of mean and standard variations we gained from the data in the questionnaire! 


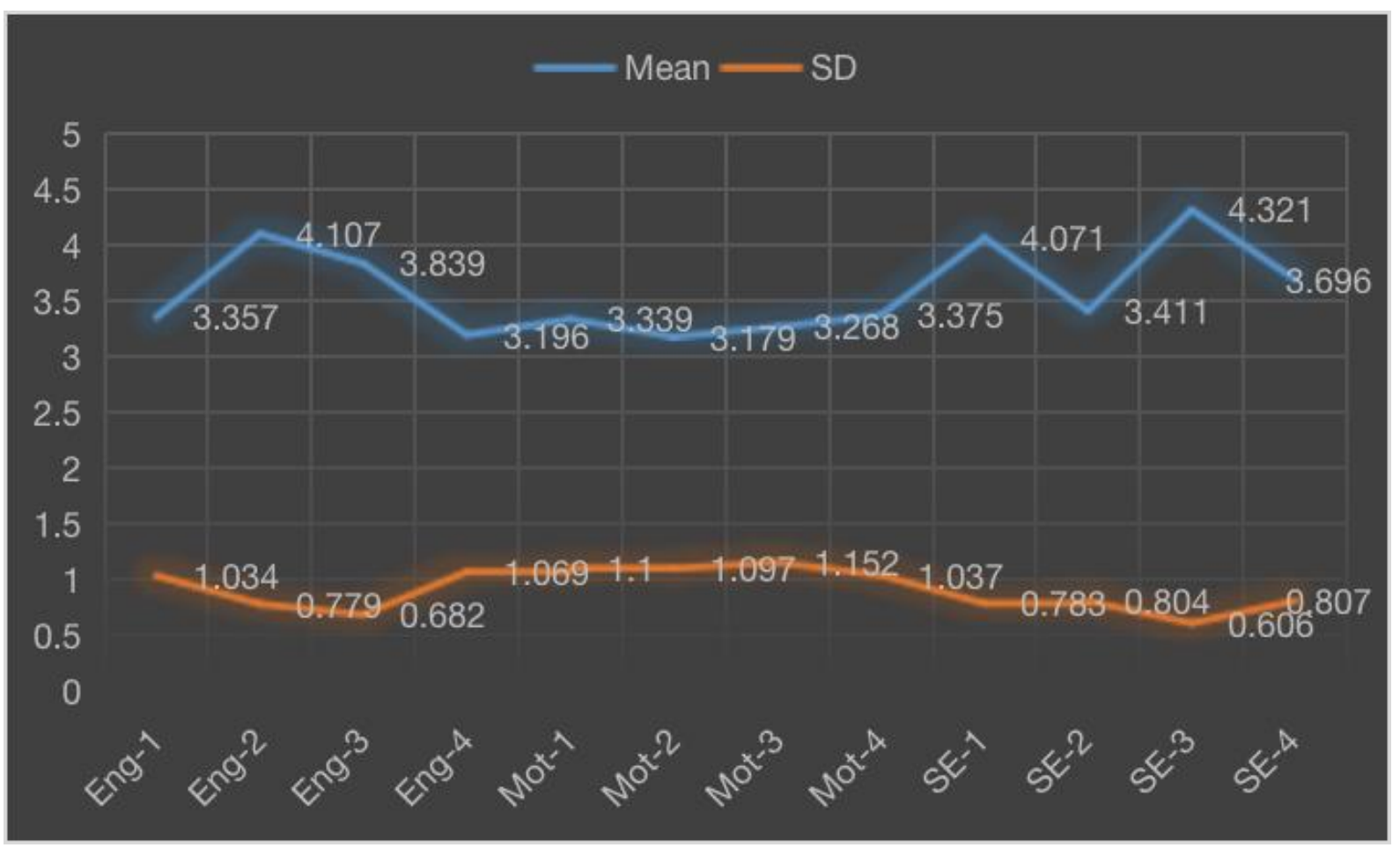

Figure 1. The graph of Means and Standard Deviations of the Questionnaire

The statistical calculation displayed above showed that the scores of standard deviations on each question were below the scores of mean on each question. The standard deviation scores were used to examine the accuracy of mean scores. It can be said that the collected data have a good accuracy since the scores of standard deviations were lower than the scores of means. It means that the data had low variability.

Table 3 and Figure 1 show that the results of each question in the questionnaire were at moderate to positive levels. It can be said that most participants had a positive engagement, motivation, and self-efficacy. To find out whether this finding affected students' achievement in passing the CLOs, we took secondary data from their classroom lecturer. These data contained each student's scores in 4 criteria of CLOs which were set by the faculty. 


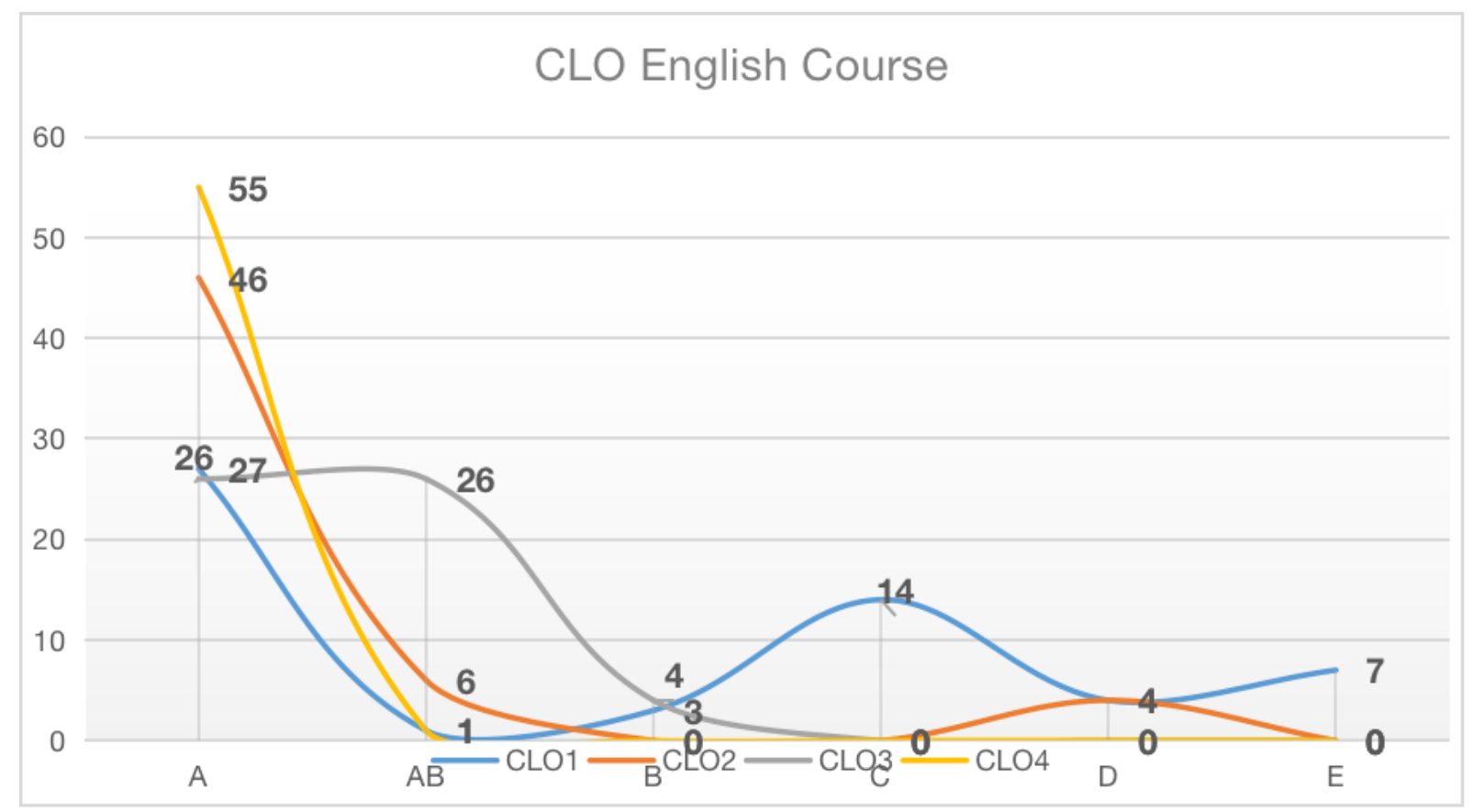

Figure 2. Students' Course Learning Outcomes

The figure above draws the results of students' assessment in completing the CLO in English class taken by participants within the number of participants in the vertical axis and the student's grades in the horizontal axis. The English course taken by participants had 4 CLO, namely CLO 1, CLO 2, CLO 3, and CLO 4. CLO 1 consisted of TOEFL-like and speaking tests. Meanwhile, CLO 2 was taken from 3 projects that students should complete during the semester. CLO 3 and CLO 4 were taken from the mid-term test and final test.

To pass CLO 1 to CLO 4, the students should at least get C at their CLO grading. In Figure 2, it can be seen that 7 students did not pass CLO 1 and 4 students did not pass CLO 2. To get a deeper investigation into this case, we called these participants who did not pass the CLOs' requirements to have an unstructured interview. Then it is known that most students who failed in CLO 1 were those who did not take or retake the TOEFL-like and speaking tests conducted by Language Center. Some did so because they failed to manage the schedule for taking the test and the rest of the students had trouble with their internet connection at the scheduled TOEFL-like and speaking tests. Furthermore, the students who failed in CLO 2 were those who were late in submitting 1 of 3 projects required in CLO 2, so automatically this decreased their scores.

Aside from the challenges faced by some students to pass the learning outcomes, more than $70 \%$ of students could still pass the CLO 1 as shown in Figure 2. The better results of 
assessments were also shown in CLO 2, CLO 3, and CLO 4. The students got quite satisfying results in CLO 3 and CLO 4 since none of them got C and below on their grades.

\section{Discussion}

The shifting of the teaching and learning system during this pandemic left people to take a moment to adapt well to the changes and situations. Both students and teachers/lecturers need to improve their technical competence to deal with virtual classrooms. In a study about elearning challenges during the COVID-19 pandemic, Putra et.al. (2020) noticed that infrastructure and connectivity might become a challenge for students in participating in their online classes during the pandemic. Accordingly, we also figured out that the students who failed to pass CLO 1 and CLO 2 were troubled with their internet connections. Hence, technology plays an important role in the achievement of CLOs during virtual learning.

The results of this study show that the participants have good motivation, self-efficacy, and engagement in joining the virtual English class during this pandemic. In line with this, other results also show that more than $80 \%$ of participants got high grades after completing the CLOs. In the previous study, Wei, Saab, \& Admiraal (2020) found that students' engagement was correlated with their self-efficacy and motivation which significantly affected their learning outcomes. On a different occasion, Hariyati, Wagino, \& Mudjito (2021) stated that motivation became a mediating variable to successful learning outcomes in virtual learning. By comparing participants' responses in the questionnaire with their assessments in CLOs, we found similar findings as stated in previous studies (Hariyati et al., 2021; MacIntyre et al., 2020; Skalka et al., 2019; Wei et al., 2020). Participants with high motivation, self-efficacy, and engagement could achieve the passing grade almost in all CLOs.

Internal factors, such as bad time management, boredom, technology, and the internet, obviously had affected the learners to reach lower grades in their CLOs (Derakhsan et al., 2021; Syahputri et al., 2020; Vadivel et al., 2021). As investigated in participants who did not pass CLO 1 and CLO2, failing to manage the time and bad internet connection became their main cause of failure to reach the outcomes.

\section{CONCLUSION AND SUGGESTION}

This research highlights the investigation of students' perceptions to cope with the challenge faced by students in the virtual classroom and of students' assessment in dealing with 
CLOs required. Most respondents had a positive engagement, self-efficacy, and also motivation to join the emergency remote learning prepared by the lecturers and institution. Nonetheless, we noticed that 7 participants did not reach the requirement to pass CLO 1 and 4 participants also did not pass CLO 2. After doing a deep investigation, we found that this failure was caused by some drawbacks faced during the running semester. Internet connection and time management became the main cause of students' failure in this case. The motivation might decrease due to bad internet connection which, further, this situation might also decrease student's engagement and self-efficacy. As the result, this might impact the assessment of each student's CLOs. We, therefore, suggest the classroom teachers and all educators give special attention to the students who might face harder drawbacks in following the emergency remote learning. However, the findings of this research proved that students with good engagement, motivation, and self-efficacy can successfully pass the required learning outcomes in the course taken.

The implication of this study is to point out the relation between students' perspective and their assessments. The findings would help the classroom teachers to evaluate their teaching strategy to maximize the assessment of CLOs. However, this research has the limitation of which the number of participants. We cordially suggest a deeper discussion with a larger number of participants for future research.

\section{BIO-PROFILE}

Lina Septianasari holds her Bachelor of Arts (in English Education) from Universitas Muhammadiyah Metro and Master of Arts ( in Linguistics) from Universitas Gadjah Mada, Yogyakarta. Currently, she is working as an English lecturer at several private and state universities in West Java, one of which is STKIP Muhammadiyah Bogor. She is passionate about language studies, such as Pragmatics, Sociolinguistics, Semantics, Syntax, etc. Corresponding email: linaseptiana27@gmail.com

Irma Wahyuni is a lecturer at STKIP Muhammadiyah Bogor. She is currently pursuing her Ph.D. in Linguistics at Universitas Pendidikan Indonesia, Bandung. Her main research interests are in linguistics and education. Corresponding email: wahyuni.irma@gmail.com 


\section{REFERENCES}

Aldhahi, M. I., Alqahtani, A. S., Baattaiah, B. A., \& Al-Mohammed, H. I. (2021). Exploring the relationship between students' learning satisfaction and self-efficacy during the emergency transition to remote learning amid the coronavirus pandemic: A cross-sectional study. Educ. Inf. Technology, 13, 1-18. https://doi.org/10.1007//s10639-021-10644-7

Ali, M. M., \& Hassan, N. (2018). Defining Concepts of Student Engagement and Factors Contributing to Their Engagement in Schools. Creative Education, 09(14). https://doi.org/10.4236/ce.2018.914157

Apuke, O. D. (2017). Quantitative Research Methods : A Synopsis Approach. Kuwait Chapter of Arabian Journal of Business and Management Review, 6(11), 40-47. https://doi.org/10.12816/0040336

Ashwin, P., \& McVitty, D. (2015). The Meanings of Student Engagement: Implications for Policies and Practices. In The European Higher Education Area. Springer International Publishing. https://doi.org/10.1007/978-3-319-20877-0_23

Azubuike, O. B., Adegboye, O., \& Quadri, H. (2020). Who gets to learn in a pandemic? Exploring the digital divide in remote learning during the COVID-19 pandemic in Nigeria. International Journal of Educational Research Open. https://doi.org/10.1016/j.ijedro.2020.100022

Bandura, A. (1997). Self-efficacy: The exercise of control. W.H. Freeman.

Besser, A., Lotem, S., \& Zeigler-Hill, V. (2020). Psychological Stress and Vocal Symptoms Among University Professors in Israel: Implications of the Shift to Online Synchronous Teaching During the COVID-19 Pandemic. Journal of Voice. https://doi.org/10.1016/j.jvoice.2020.05.028

Cheng, X., Chan, L. K., Cai, H., Zhou, D., \& Yang, X. (2021). Adaptions and perceptions on histology and embryology teaching practice in China during the Covid-19 pandemic. Translational Research in Anatomy, 24(100115), 1-10. https://doi.org/10.1016/j.tria.2021.100115

Cohen, L., Manion, L., \& Morrison, K. (2007). Research Methods in Education (6th Editio). Routledge.

Coman, C., Țîru, L. G., Meseșan-Schmitz, L., Stanciu, C., \& Bularca, M. C. (2020). Online teaching and learning in higher education during the coronavirus pandemic: Students' perspective. Sustainability, 12(24), 1-22. https://doi.org/10.3390/su122410367

Derakhsan, A., Kruk, M., Mehdizadeh, M., \& Pawlak, M. (2021). Boredom in online classes in the Iranian EFL context: Sources and solutions. System, 101. https://doi.org/10.1016/j.system.2021.102556

Dhawan, S. (2020). Online Learning: A Panacea in the Time of COVID-19 Crisis. Journal of Educational Technology Systems, 49(1), 5-22. https://doi.org/10.1177/0047239520934018 
Espino-Díaz, L., Fernandez-Caminero, G., Hernandez-Lloret, C. M., Gonzalez-Gonzalez, H., \& Alvarez-Castillo, J. L. (2020). Analyzing the impact of COVID-19 on education professionals. Toward a paradigm shift: ICT and neuroeducation as a binomial of action. Sustainability (Switzerland), 12(14), 1-10. https://doi.org/10.3390/su12145646

Gonzalez, T., Rubia, M. A., Hincz, K. P., Comas-Lopez, M., Subirats, L., Fort, S., \& Sacha, G. M. (2020). Influence of COVID-19 confinement on students' performance in higher education. PloS ONE, 15(10), e0239490. https://doi.org/10.1371/journal.pone.0239490

Hariyati, N., Wagino, \& Mudjito. (2021). Investigating virtual learning on students' learning outcomes in urban and rural areas. Dinamika Pendidikan, 16(1), 54-63. https://doi.org/10.15294/dp.v16i1.28661

Heng, K., \& Sol, K. (2020a). Online learning during COVID-19: Key challenges and suggestions to enhance effectiveness. Cambodian Education Forum. https://www.researchgate.net/publication/346719308_Online_learning_during_COVID19_Key_challenges_and_suggestions_to_enhance_effectiveness

Heng, K., \& Sol, K. (2020b). Online learning during COVID-19: Key challenges and suggestions to enhance effectiveness. Cambodian Education Forum (CEF), December 1-15.

Hussein, E., Daoud, S., Alrabaiah, H., \& Badawi, R. (2020). Exploring undergraduate students' attitudes towards emergency online learning during COVID-19: A case from the UAE. Children and Youth Services Review, 119, 1-6. https://doi.org/10.1016/j.childyouth.2020.105699

Kosyicheva, M. A., \& Tikhonova, E. V. (2021). Students' self-efficacy and motivation in emergency remote learning. The 12th International Conference on E-Education, E-Business, EManagement, and E-Learning, 157-162. https://doi.org/10.1145/3450148.3450207

Lapitan, L. D., Tiangco, C. E., Sumalinog, D. A. G., Sabarillo, N. S., \& Diaz, J. M. (2021). An effective blended online teaching and learning strategy during the COVID-19 pandemic. Education for Chemical Engineers, 35, 116-131. https://doi.org/10.1016/j.ece.2021.01.012

MacIntyre, P. D., Gregersen, T., \& Mercer, S. (2020). Language teachers' coping strategies during the Covid-19 conversion to online teaching: Correlations with stress, wellbeing, and negative emotions. System, 94, 102352. https://doi.org/10.1016/j.system.2020.102352

Mahyoob, M. (2020). Challenges of e-Learning during the COVID-19 Pandemic Experienced by EFL Learners. Arab World English Journal, 11(4). https://doi.org/10.24093/awej/vol11no4.23

Mozhaeva, G., Feshchenko, A., \& Kulikov, I. (2014). E-learning in the Evaluation of Students and Teachers: LMS or Social Networks? Procedia - Social and Behavioral Sciences, 152, 127-130. https://doi.org/10.1016/j.sbspro.2014.09.168

ÖZÜDOĞRU, G. (2021). Problems faced in distance education during Covid-19 Pandemic. Participatory Educational Research, 8(4). https://doi.org/10.17275/per.21.92.8.4

Pal, D., \& Vanijja, V. (2020). Perceived usability evaluation of Microsoft Teams as an online learning platform during COVID-19 using system usability scale and technology acceptance 
model in India. Children and Youth Services Review, 119, 105535. https://doi.org/10.1016/j.childyouth.2020.105535

Patricia, A. (2020). College Students' Use and Acceptance of Emergency Online Learning Due to COVID-19. International Journal of Educational Research Open, 100011. https://doi.org/10.1016/j.ijedro.2020.100011

Putra, P. O. H., Aini, Q., Budiarto, M., \& Rahardja, U. (2020). Exploring e-learning challenges during the global COVID-19 pandemic: A review. Jurnal Sistem Informatika (Journal of Information System), 16(2).

Riadi, E. (2018). Statistik SEM: Structural Equation Modeling dengan LISREL. Andi.

Skalka, J., Drlik, M., \& Obonya, J. (2019). Automated assessment in learning and teaching programming languages using virtual learning environment. IEEE Global Engineering Education Conference, EDUCON, April-2019(April), 689-697. https://doi.org/10.1109/EDUCON.2019.8725127

Syahputri, V. N., Rahma, E. A., Setiyana, R., Diana, S., \& Parlindungan, F. (2020). Online learning drawbacks during the Covid-19 pandemic: A psychological perspective. EnJourMe (English Journal of Merdeka): Culture, Language, and Teaching of English, 5(12), 108-116.

Turmudi, D. (2020). English scholarly publishing activities in the industrial revolution 4.0: What, why, and how? English Language Teaching Educational Journal, 3(1), 52-63

Vadivel, B., Mathuranjali, M., \& Kalil, N. R. (2021). Online teaching: Insufficient application of technology. Materialstoday: Proceedings. https://doi.org/10.1016/j.matpr.2021.01.454

Wei, X., Saab, N., \& Admiraal, W. (2020). Assessment of cognitif, behavioral, and affective learning outcomes in Massive Open Online Course: A systematic literature review. Computers and Education, 163. https://doi.org/10.1016/j.compedu.2020.104097

Zulkosky, K. (2009). Self-Efficacy: A Concept Analysis. Nursing Forum, 44(2). https://doi.org/10.1111/j.1744-6198.2009.00132.x 